\section{China, Pastoralists in}

HERMANN KREUTZMANN

Freie Universitaet Berlin, Germany

One of the great promises of all revolutions that took place during the twentieth century was the vision of a better life for rural populations. The Chinese Revolution was no exception to this rule. Within one decade of its accomplishment major interventions in the rural sector took place in a threestep approach. First, mutual aid teams were formed to enhance cooperation between farmers in the villages. The second step intervened in agricultural production by applying economies of scale and by borrowing from experiences in the formation of cooperative societies. Agricultural production cooperatives preceded the other major intervention in rural areas. Within the so-called "democratic reforms" and the "Great Leap Forward" a new structure was implemented that built on collectivization and the introduction of peoples' communes. What applied to farmers was extended to nomads as well. Nomads became the prime "objects" of tangible modernization effects.

For the pastoral sector the collective ownership of livestock and the introduction of permanent winter settlements were among the key features and visible signs of a changing pattern of social organization. The formation of collective work teams and production brigades influenced the division of labor and specialization within animal husbandry practices. With these reforms a slogan developed that was repeated and used for nearly two decades: "take grain as the key link" (yi liang wei gang), which during the Cultural Revolution (1966-76) - the subsequent major intervention phase-resulted in a "grain first" policy. Repeatedly, analysts have interpreted these interventions as a strategy to expand crop farming at all costs and to reduce the cost of animal husbandry. Peter Ho has questioned this interpretation and warned against taking it as a reduction strategy: "From the very beginning the full slogan ran: 'Take grain as the key link for overall development and diversification' ( $y i$ liang wei gang, quanmian fazhan, duozhong jingying). This slogan was accompanied by another: 'Agriculture, forestry, and animal husbandry are interdependent; not one can be omitted' (nong, lin, mu san zhe huxiangyilai; queyi bu ke)" (Ho 2003: 50). He emphasizes the respective interventions in all sectors, including animal husbandry, as a strategy to enhance food security for society.

Significant change to rural areas and pastoral communities was brought about when, after 1978, Deng Xiaoping's "four modernizations" were implemented by "reform and opening-up" (gaige kaifang) strategies. The introduction of the "household responsibility system" and the dissolution of the peoples' communes started the process of decollectivisation. For three decades some observers noted a revival of a "nomadic way of life"; others perceive the distribution of communal livestock among households and the contracting of grassland user rights to them as the beginning of deregulation and privatization in the pastoral sector (Goldstein and Beall 2002; Kreutzmann 2012). For nearly two decades this strategy was the conventional approach in giving certain degrees of freedom to pastoralists.

In recent years the planning vacuum seems to have been filled again. With the "four-way

The Wiley Blackwell Encyclopedia of Race, Ethnicity, and Nationalism, First Edition.

Edited by John Stone, Rutledge M. Dennis, Polly S. Rizova, Anthony D. Smith, and Xiaoshuo Hou.

(c) 2016 John Wiley \& Sons, Ltd. Published 2016 by John Wiley \& Sons, Ltd.

DOI: $10.1002 / 9781118663202$.wberen 409 
scheme" (sipeitao jianshe) an attempt to improve infrastructure and to provide necessary public services was introduced that specifically affected living and production in the grassland areas. Four key "constructions" were identified that aimed to result in significant changes in livelihood conditions: first, based on current experiences with appropriate construction techniques, an attempt to introduce "modern" housing and suitable livestock shelters has been implemented with provision of significant external subsidies. Second, in order to optimize pasture utilization, fencing of pastures has been identified as an efficient tool to rationalize animal husbandry. Third, social infrastructure including schools and health facilities has been made available to pastoralists. Fourth, pastureuser rights have been contracted to pastoral households on a private ownership basis. This strategy was started prior to the turn of the millennium's "Great Development of the West" campaign in which the "four constructions" fitted well. Shortly afterwards a new turn and modification of planning came up that has been characteristic of the past decade and that might provide direction for the future.

As a result of the severe degradation of a significant share of pastures on the Tibetan Plateau and in adjacent regions such as Xinjiang, further measures of intervention have been introduced that are justified and rationalized on ecological and economic grounds (Sheehy, Miller, and Johnson 2006). The "restore pastures to grass" (tuimu huancao) campaign as part of the wider framework of "farmland to forest" (tuigeng huanlin) is accompanied by slogans such as "grain to green" and aims at poverty reduction in a comprehensive policy approach. "Poverty alleviation through migration" (yimin fupin) suggests a new dynamic involving people to be moved. Resettlement schemes introduced since 2002 aim at population concentration in "resettlement in high pastures" or "agro-pastoral resettlement in lowland regions." Both envisage concentrated settlements resembling townships that provide all infrastructural assets for a decent life. Animal husbandry will significantly change as schemes that concentrate livestock in central stables/shelters and that provide sophisticated livestock-specific agricultural extension and veterinary care require fewer staff. The rationalization of livestock-breeding and pasture utilization releases a workforce that is meant to become migrant workers and laborers in cities. During the past five years these strategies have become more specific, and "ecological migration" (shengtai yimin) is adopted to address both objectives. On the one hand, environmental protection is supposed to be enhanced by out-migration of pastoralists and abandoning of previous regularly utilized pastures. The aim is to preserve biodiversity and water sources by reducing overgrazing and environmental degradation by "depopulating the Tibetan Grasslands" (Foggin 2008). Migration is supposed to bring a "modernization" of lifestyles by providing urban amenities in new forms of settlements above a minimum size to enable the provision of adequate infrastructure. The new settlements are part of a hierarchical setup of towns that provide resources according to their sizes. Sedentarization seems to be the strategy of the hour, aiming at nearly all pastoralists of the Tibetan steppe. Little choice remains for alternative lifestyles and production strategies when resettlement is the only adaptive strategy implemented that deals with challenges of climate, global, and social change.

Probably this new strategy is unique when it comes to the resettlement of people, the exclusion of space from human utilization, and the consequences of this interference. In other contexts pastoralists were settled as well, as seen in the Mongolian and Soviet 
examples (Humphrey and Sneath 1999). The adoption of a "green argument" to stop degradation conforms well to western notions of nature protection. Abandoning cultural landscapes, however, does not necessarily invoke a return to nature. Pastoral strategies have proved over centuries that a resource can be utilized in a sustainable manner. The indigenous knowledge accumulated by pastoralists over many generations seems too valuable to be just neglected or omitted (Miller 2002).

Leaving the ecological argument aside, the "modernization" argument seems to be an even stronger one. Intervention in the form of "ecological migration" seems to aim at changes in lifestyles. The welfare gap between affluent urbanites of coastal eastern China and rural populations of the interior, west, mountains and steppes has been widening. A society has to decide how to handle such a situation if the stipulated aim is to mitigate the effects of social differentiation. The Chinese government has opted for the complete handling of the situation when it announced the "final settlement of all nomads" in May 2013 (Kreutzmann 2013). Critics of the resettlement schemes suggest that in contrast to a top-down approach "community-co-management" (Foggin 2008: 31) could be helpful by incorporating local stakeholders and the pastoral households, as equal partners in a joint effort to design development packages that are acceptable to all. Thus, valuable indigenous knowledge that regional planners nearly always lack and neglect could be made useful for tackling a complex constellation that calls for holistic and sensitive approaches.
SEE ALSO: Beijing Consensus; Economic Development; Mao Zedong (1893-1976); Market Transition; Uneven Development

\section{REFERENCES}

Foggin, Mark. 2008. "Depopulating the Tibetan Grasslands. National Policies and Perspectives for the Future of Tibetan Herders in Qinghai Province, China." Mountain Research and Development 28(1): 26-31.

Goldstein, Melvyn and Cynthia Beall. 2002. "Changing Patterns of Tibetan Nomadic Pastoralism." In Human Biology of Pastoral Populations, edited by William Leonard and Michael Crawford, 131-50. Cambridge: Cambridge University Press.

Ho, Peter. 2003. "Mao's War against Nature? The Environmental Impact of the Grain-First Campaign in China." China Journal 50: 37-59.

Humphrey, Caroline and David Sneath. 1999. The End of Nomadism? Society, State and the Environment in Inner Asia. Durham, NC: Duke University Press.

Kreutzmann, Hermann., ed. 2012. "Pastoral Practices in Transition: Animal Husbandry in High Asian Contexts." In Pastoral Practices in High Asia. Agency of "Development" Effected by Modernisation, Resettlement and Transformation, 1-29. Dordrecht: Springer.

Kreutzmann, Hermann. 2013. "The Tragedy of Responsibility in High Asia: Modernizing Traditional Pastoral Practices and Preserving Modernist Worldviews." Pastoralism: Research, Policy and Practice 3: 7.

Miller, Dan. 2002. “The Importance of China's Nomads. The Sustainable Future Development of China's Rangelands Depends on Integrating Nomads' Indigenous Knowledge." Rangelands 24(1): 22-24.

Sheehy, Dennis P., Daniel Miller, and Douglas A. Johnson. 2006. "Transformation of Traditional Pastoral Livestock Systems on the Tibetan Steppe." Sécheresse 17(1-2): 142-51. 